\title{
Mundo virtual y posverdad. Nueva realidad entre el poder y los medios en el siglo XXI
}

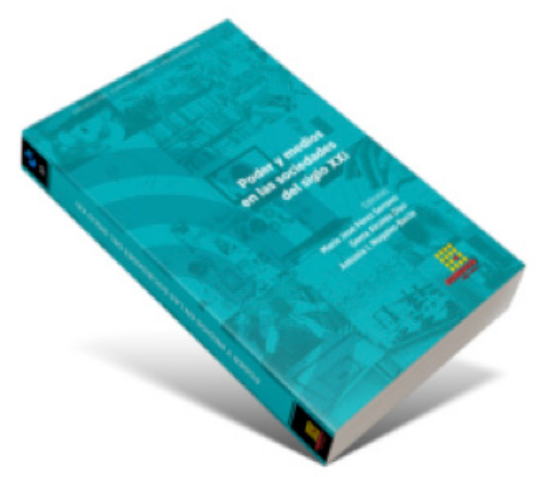

\author{
Poder y Medios de Comunicación \\ en las sociedades del siglo XXI
}

\author{
María José Pérez-Serrano, Gema Alcolea- \\ Díaz y Antonia Isabel Nogales-Bocio (Eds.) \\ Egregius, Sevilla, 2018 \\ 314 páginas
}

Reseña por Daniel Moya López

\begin{abstract}
Son tiempos inciertos. A veces uno puede retrotraerse a cómo serían aquellos años tras el nacimiento de la imprenta. Internet nació hace tiempo, pero las redes sociales han desfasado las medidas temporales. Todo es tan vertiginoso que del 2.0 al 3.0 no pasa ni una década, y sin llegar a comprender bien la fase inicial. Este tiempo incierto, no obstante, aún quedan certidumbres: hay un poder y hay unos medios. Distinto es que sepamos comprender quién es el poder y quiénes son los medios entre esta vorágine en la que la subida del consumo de antidepresivos demuestra que ni hasta nosotros mismos somos capaces de reconocernos.

Bien, Poder y medios en las sociedades del siglo XXI se plantea el reto de intenta comprender las dos cuestiones anteriores. Objetivo ambicioso y que el libro no logra alcanzar por dos motivos: el primero es que el título no hace justicia al contenido interior; el segundo es que esto posee toda la lógica del mundo si se tiene en cuenta el contexto de su elaboración. Nacido como un compendio de algunos de los trabajos que se expusieron en el simposio de Poder y Medios en el III Congreso Internacional Comunicación y Pensamiento del pasado marzo, es imposible abarcar una relación tan abstracta como su título indica.
\end{abstract}


Ahora bien, hecha esta puntualización, la obra posee reflexiones a nivel micro imprescindibles para entender lo abstracto de lo macro. Las coordinadoras (Pérez Serrano, Alcolea-Díaz y Nogales-Bocio) dividen en tres ejes temáticos la estructura del libro. De ellos, el más sobresaliente es el segundo, enfocado a las tecnologías de la información y la comunicación (TICs) desde distintos ámbitos. Excelente es el capítulo que divaga sobre la ley promulgada en Alemania para hacer frente a los mensajes en redes. Una necesidad imperiosa en los tiempos actuales de los que su autor, Vlatislav Stavinoha, recalca que los delitos y sanciones recaen sobre los proveedores y no sobre el usuario, siendo responsabilidad de las empresas de internet evitar contenidos perniciosos para la sociedad.

José Candón-Mena hace una gran reflexión crítica acerca de la conjugación entre democracia y TICs, en la que se aboga sobre las potencialidades de ésta para generar una nueva forma de ejercer la propia democracia. A destacar su advertencia de cómo la propia oligarquía (a través también de los propios medios) ha criticado las posibilidades de la Red por este peligro democratizador, que amenaza su situación hegemónica. Reflexión que se zanja con una frase demoledora: "Sin embargo para ser justos hay que partir también de los déficits del sistema mediático tradicional, pues la crisis de legitimación democrática no surgió con internet, como tampoco lo hicieron las fake news, la radicalización populista, ni los discursos del odio sobre los que el sistema mediático tradicional haría bien en hacer una profunda autocrítica".

María Romero Calmache e Inés García Herrer prosiguen con la línea anterior, esta vez con un análisis de la presencia del movimiento antitaurino en la prensa digital española. De su trabajo específico con esa lucha animalista, es extrapolable una necesidad en estos tiempos de barracones y trincheras sociales: la convergencia de sus movimientos frente a una estructura de poder bien armada. Tamara Álvarez Robles expone las principales causas por las que no se implementa el voto electrónico. En tiempos donde, como ya se ha advertido, las TICs podrían ofrecerse como una herramienta valiosísima para la calidad democrática, "la confianza y la seguridad" son las principales razones por las que el voto electrónico aún es una realidad lejana.

A través de dos mundos tan distintos, este bloque temático también ofrece otras miradas distintas. Siria, sumida en una guerra civil desde 2011 y con casi 20 millones de habitantes, y el Valle de Mena, un municipio burgalés que no alcanza los 4.000. En el país árabe se analiza las caricaturas como comunicación alternativa frente a una prensa controlada, mientras que en la localidad de Burgos se hace lo propio con la comunicación institucional en un ayuntamiento pequeño. Dos formas de comunicar muy distintas que copan espacios distintos en la actualidad. Una en peligro de extinción, otra en pleno auge. 
El tercer bloque temático analiza, principalmente, la nueva realidad virtual en el consumo mediático y la necesidad de ejercer como contrapoder en este nuevo escenario. El trabajo de Luis Miguel Romero-Rodríguez, Ana Luisa Valle Razo y Ángel Torres Toukoumidis esboza a una ciudadanía con serios problemas para integrar el exceso de información en un clima basado en la posverdad. En una posverdad que, muy acertadamente, los autores definen como "un ecosistema en el que impera la manipulación de creencias y emociones, de forma deliberada, con el fin de influir en el comportamiento social", frente a la definición más aséptica y benevolente de la Real Academia Española de la Lengua. De este capítulo, a modo de anécdota, pero para hacer reflexionar si cabe la posibilidad, es la mansalva de términos anglicistas que se agolpan en los estudios en español, configurándose una lectura en spanglish que a menudo es ilegible e incomprensible. Frente a la hegemonía anglosajona, no está de más apostar por términos claros para la tercera lengua más hablada en todo el planeta.

María Luisa Cárdenas Rica y David Polo Fernández ponen el foco en las pruebas de verificación contra esa misma posverdad, instaurada principalmente en el ámbito político y que ha dado lugar al nacimiento de plataformas de contrapoder para luchar contra ello. Ambos autores analizan el caso de El Objetivo, en La Sexta (España), si bien trabajos suyos posteriores ahondan en otros casos como el de Maldito Bulo. Es éste un espacio que, a buen seguro, se hará habitual en la agenda académica en los próximos años.

El bloque lo termina Patricia Torres Hermoso y Antonia Isabel Nogales Bocio, que a raíz de la tesis doctoral de la primera, se plantean la influencia del relato de presión a nivel social y periodístico en el endurecimiento penal ante casos de sucesos tan mediáticos como el de Asunta. Además del contenido, también interesa a nivel teórico los criterios de selección de los periódicos analizados.

La sombra a la obra la pone el primer bloque temático, cuyo eje común es su situación geográfica, Latinoamérica. Una región de notable atractivo para investigar por su situación geopolítica, pero que ofrece estudios en este caso algo más pobres y más criticables. Ejemplo es el análisis que se hace de la Ley Orgánica de Comunicación de Ecuador, sujeta a una intensa crítica basado en criterios de la Freedom House, cuya financiación depende del gobierno de Estados Unidos. Una contradicción a tener en cuenta. De todos los trabajos presentados en este bloque temático surge también una llamativa conclusión, la escasa interacción de los candidatos electorales con la ciudadanía pese a la mayor cercanía y circulación de las redes sociales. Si unimos esto a lo expuesto por los trabajos sobre democracia y TICs, se une una clara visión de deficiencia del uso democrático de este nuevo mundo virtual, infectado hasta el corazón del virus de la posverdad.

Merece también mención especial al trabajo que pretende la serie de Comunicación y Pensamiento como una apuesta necesaria en estos tiempos de incertidumbre, confusión y la más que citada posverdad. Con mejor o peor resultado, la iniciativa posee una plausibilidad cargada de dignidad frente a una academia alejada de los valores esenciales de Platón. El propio pensamiento y reflexión parece desterrado de aquel templo en el que se rendía culto frente al sonrojo que produce la mercantilización universitaria en todas sus expresiones. 
En definitiva, aunque se hace necesaria completar los trabajos micros de este libro con otros estudios para alcanzar una visión más global que alcance a cumplir el objetivo general que se propone, no debe caer en saco roto las virtudes de sus páginas de la que se pueden extraer e hilar reflexiones más que interesantes que nos ayuden, aunque sea un poco, a obtener un ansiolítico de comprensión en estos tiempos que desfasan a cualquiera que atreva a detenerse a escuchar a su cabeza por un instante. 